Bogdan Kulik MSF${ }^{1}$

https://orcid.org/000-0002-8627-3821; kulikbogdan@op.pl

Uniwersytet im. Adama Mickiewicza w Poznaniu

\title{
Eschatologia w teorii i w praktyce. Próba prezentacji zagadnienia na podstawie wybranych tekstów ks. Jana Berthiera MS
}

\section{Streszczenie}

Artykuł jest próbą prezentacji dwóch tekstów ks. Jana Berthiera MS - założyciela Misjonarzy Świętej Rodziny: traktatu o rzeczach ostatecznych i praktycznej metody towarzyszenia umierającym. Celem artykułu nie jest krytyczna analiza eschatologii Berthiera, lecz wykazanie na jej przykładzie konieczności łączenia akademickiego wykładu eschatologii (teoria) z duszpasterstwem (praktyka). Dokonana prezentacja prowadzi do trzech wniosków: 1) nieustająca konieczność obecności eschatologii w nauczaniu i praktyce Kościoła; 2) potrzeba aktualizowania rozumienia jej treści i sposobu przekazu; 3) waga spójności teorii i praktyki eschatologicznej.

Słowa kluczowe: eschatologia, ars moriendi, ks. Jan Berthier MS

\section{Abstract}

Eschatology in Theory and in Practice. An Attempt to Present the Issue Based on Selected Texts of Fr. Jan Berthier MS

The article is an attempt to present two texts by Fr. Jan Berthier MS - Founder of the Missionaries of the Holy Family: a treaty on the last things and a practical method of accompanying the dying. The aim of this article is not to critically analyze Berthier's eschatology, but to demonstrate on its example the necessity

\footnotetext{
1 Bogdan Kulik MSF - dr, Misjonarz Świętej Rodziny, wykładowca teologii dogmatycznej w Wyższym Seminarium Duchownym Misjonarzy Świętej Rodziny w Kazimierzu Biskupim, zajęcia zlecone na Wydziale Teologicznym UAM w Poznaniu, duszpasterz krajowy Apostolstwa Dobrej Śmierci (apostolstwo.pl), redaktor naczelny kwartalnika „Nadzieja i Życie".
} 
of combining academic lecture of eschatology (theory) with pastoral care (practice). The presentation leads to three conclusions: 1 ) the continuing need for presence of eschatology in the teaching and practice of the Church;2) the need to update the understanding of its content and method of its communication; 3 ) the importance of coherence of eschatological theory and practice.

Keywords: eschatology, ars moriendi, Fr. John Berthier MS

Postulat łączenia teorii i praktyki w eschatologii nie jest niczym nowym. W sposób szczególny zaistniał dzięki tzw. „przełomowi eschatologicznemu" w połowie zeszłego stulecia². Główny sposób jego realizacji widzi się przede wszystkim w teologiach politycznych Jürgena Moltmanna i Johanna Baptisty Metza, które bywają prezentowane pod wspólnym szyldem: „eschatologia i praktyka”. Niejednokrotnie o konieczności eschatologii, która z teorii staje się praktyką życia, przypominał także Joseph Ratzinger: jako profesor teologii ${ }^{4}$, jako kardynał ${ }^{5}$, jako papież i jako papież emeryt ${ }^{7}$. Mimo że w ostatnich latach pojawiają się bardzo interesujące przyczynki z zakresu eschatologii akademickiej ${ }^{8}$, a także inicjatywy o charakterze praktycznym ${ }^{9}$, jednak namysł nad koniecznością łączenia teorii i praktyki eschatologicznej musi być podejmowany wciąż na nowo, gdyż w grę wchodzi wieczny los człowieka, całej ludzkości i świata.

Niniejszy artykuł jest próbą podjęcia tego zagadnienia na podstawie działalności pisarskiej i duszpasterskiej założyciela Misjonarzy Świętej

2 Zob. A. Nitrola, Trattato di escatologia, vol. 1: Spunti per un pensare escatologico, Cinisello Balsamo (Milano) 2001, s. 34-40.

3 Zob. A. Nitrola, Trattato, s. 79-90.

4 Zob. J. Ratzinger, Eschatologia i utopia, „Communio” 38 (2018) nr 3-4, s. 9.

5 Zob. Bóg i świat: wiara $i$ życie $w$ dzisiejszych czasach, z kardynałem Josephem Ratzingerem (Benedyktem XVI) rozmawia Peter Seewald, przekł. G. Sowinski, Kraków 2005, s. $399-400$.

6 Zob. Światłość świata. Papież, Kościół i znaki czasu, Benedykt XVI w rozmowie z Peterem Seewaldem, przekł. P. Napiwodzki, Kraków 2011, s. 185.

7 Zob. Benedykt XVI, Ostatnie rozmowy, rozmawia P. Seewald, Kraków 2016, s. 279.

8 Np. „Verbum Vitae” 36 (2019): Kara wieczna-czym jest?; „Communio” 38 (2018) nr 3-4: Kryzys eschatologii.

9 Np. działalność Apostolstwa Dobrej Śmierci, zob. apostolstwo.pl. 
Rodziny, ks. Jana Berthiera MS (1840-1908) ${ }^{10}$, na przykładzie dwóch tekstów jego autorstwa: Breve compendium theologiae dogmaticae et moralis i Méthode pour assister les mourants. Oba dzieła zawierają, choć w różnym stopniu, treści eschatologiczne. W dotychczasowych opracowaniach polskojęzycznych pierwsze jest zaledwie wspominane ${ }^{11}$, natomiast drugie doczekało się kilku szczegółowych komentarzy ${ }^{12}$. Celem artykułu nie jest krytyczna i dogłębna analiza eschatologii Berthiera, lecz ukazanie na jej przykładzie konieczności łączenia teorii i praktyki eschatologicznej. Na podstawie dokonanej prezentacji zostanie podjęta próba sformułowania kilku wniosków.

\section{Compendium Theologiae Dogmaticae et Moralis}

W 1887 roku, po ponad 20 latach pracy duszpasterskiej, Berthier opublikował po łacinie Compendium Theologiae Dogmaticae et Moralis ${ }^{13}$.

10 Na temat życia i dzieła Berthiera zob. H.J. Barnhoorn, Ks. Jan Berthier. Założyciel Misjonarzy Św. Rodziny 1840-1908, tłum. Z. Kruża, Katowice 1973; „, Cor unum et anima una”. Księga Jubileuszowa ku czci księdza Jana Berthier Założyciela Zgromadzenia Misjonarzy Świętej Rodziny zokazji 100-lecia jego śmierci, red. A.J. Sobczyk, Pelplin 2009; zob. E. Jost, Jean Berthier (1840-1908). Missionar von La Salette und Gründer der MSF, w: ,...Zu denen in der Ferne gehen...”. Missionare von der Heiligen Familie (1895-1995), Hrsg. von F. Jürgensmeier, Mainz 1995, s. 83-110; E. Jost, Ksiądz Jan Berthier. Założyciel Zgromadzenia Misjonarzy Świętej Rodziny. Positio, t. 1: Exposé o cnotach (Informatio), t. 2: Summariumi, tłum. J. Drążkiewicz, M. Ferenc, Pelplin 2007.

11 Zob.np.: A. Bajorski, Pisarstwo Księdza Jana Berthier ze szczególnym uwzględnieniem „Kult i naśladowanie Świętej Rodziny”, w: „Cor unum et anima una”. Księga Jubileuszowa, s. 104; A.J. Sobczyk, Ksiadz Jan Berthier jako pisarz, w: „Cor unum et anima una”. Księga Jubileuszowa, s. 320; P. Krupa, Osoba i życie ks. Jana Berthier, w: „Cor unum et anima una”. Księga Jubileuszowa, s. 270.

12 Zob. W. Biedrzycki, Przy łożu śmierci. „Metoda towarzyszenia umierającym” ks. Jana Berthiera, w: Śmierć $i$ wiara w życie pośmiertne w świetle nauk przyrodniczych i humanistycznych, red. M. Machinek, Olsztyn 2003, s. 266 (Biblioteka Wydziału Teologii, 17); A. Bajorski, „Metoda asystowania umierającym” Księdza Jana Berthier jako model metody ogłaszania Królestwa Bożego, w: „Cor unum et anima una”. Księga Jubileuszowa, s. 95-101; M. Machinek, Towarzyszyć w ostatniej drodze. „Metoda asystowania umierającym” ks. Jana Berthier a współczesna troska o umierających, w: „Cor unum et anima una”. Księga Jubileuszowa, s. 79-94; E. Färber, Towarzyszyć umierającym. Pastoralne wskazówki duszpasterza Jana Berthiera MS (1840-1908) oraz ich dalszy rozwój w regułach zakonnych Misjonarzy Świętej Rodziny, „Nadzieja i Życie” 2 (2017), s. 14-17; 3 (2017) s. 4-7.

13 J. Berthier, Compendium Theologiae Dogmaticae et Moralis. Una cum Praecipuis Notionibus Theologiae Canonicae, Liturgicae. Pastoralis et Mysticae, ac Philosophiae Christianae, La Salette-Parisiis $1898^{4}$. Niestety w zbiorach polskich nie zachował się egzemplarz pierwszego wydania. 
W zamyśle autora, wyrażonym w tytule, był to podręcznik przedstawiający zwięźle podstawowe punkty doktryny katolickiej z zakresu teologii. W 1902 roku tekst został przetłumaczony przez samego Berthiera na język francuski ${ }^{14}$, a także doczekał się tłumaczenia na język włoski ${ }^{15}$, które będzie punktem odniesienia w niniejszym artykule. Podręcznik cieszył się wielką popularnością wśród ówczesnego duchowieństwa zarówno francuskiego, jak i włoskiego, o którym oprócz wysokiego nakładu kolejnych edycji świadczą przede wszystkim pochwały ze strony papieża Leona XIII przekazane przez kard. Mariano Rampollę ${ }^{16}$, a także biskupów, profesorów i przełożonych seminaryjnych. Przyczyny sukcesu książki Berthiera wyjaśnia tekst Wstępu:

Kapłani nadmiernie obciążeni zajęciami będą mogli dzięki tej pozycji łatwo przypomnieć sobie i utrwalić wiadomości tak konieczne, a wcześniej nabyte. Dlatego pokornie i z naciskiem prosimy naszych współbraci w kapłaństwie, którzy nie mają czasu na lekturę dzieł bardziej obszernych, alby przynajmniej to dzieło czytali często ${ }^{17}$.

Berthierowi przyświecał jeden cel: ułatwić seminarzystom i kapłanom przyswojenie i ugruntowanie teorii, która miała stać się fundamentem i treścią ich duszpasterskiej praktyki. Nie dziwi zatem układ dzieła, który posiada strukturę typową dla podręcznika z przełomu XIX i XX wie$\mathrm{ku}^{18}$. Treść podzielono na dysertacje składające się z traktatów z: rozdziałami, artykułami, paragrafami, punktami i podpunktami. Po bardzo krótkim Wprowadzeniu filozoficznym ${ }^{19}$ następuje obszerna część teologiczna, podzielona na Teologię dogmatyczną ${ }^{20}$ i Teologię moralną ${ }^{21}$. W części

14 J. Berthier, Abrégé de Théologie Dogmatique et Morale. Avec les Notions les plus Importantes de Droit Canon, de Liturgie, de Pastorale, de Théologie mystique et de philosophie chrétienne, LyonParis, 19274; por. H.J. Barnhoorn, Ks. Jan Berthier, s. 142.

15 J. Berthier, Sommario di Teologia Dogmatica e Morale. Colle Nozioni più Importanti di Diritto Canonico, di Liturgia, di Teologia Mistica e di Filosofia Cristiana, Torino 1933.

16 M. Rampolla, Lettera di S. Eminenza il Card. Rampolla, w: J. Berthier, Sommario, s. 4.

17 Prefazione, w: J. Berthier, Sommario, s. 9-10.

18 Na temat manualistyki zob. G. Pozzo, La manualistica, w: Storia della teologia, a cura di R. Fisichella, vol. 3: Da Vitus Pichler a Henri de Lubac, Roma-Bologna 1996, s. 309-334.

19 J. Berthier, Sommario, s. 11-20.

20 J. Berthier, Sommario, s. 21-465.

${ }^{21}$ J. Berthier, Sommario, s. 467-866. 
dogmatycznej znalazło się miejsce także na eschatologię. Berthier zawarł ją w dysertacji IV: O Bogu odpłacającym ${ }^{22}$. W skład dysertacji wchodzą dwa traktaty: 0 celu człowieka aż do końca świata i $O$ końcu świata. Według takiego schematu autor przedstawił podstawowe zagadnienia eschatologii indywidualnej i powszechnej.

Należy zaznaczyć, że doktryna rzeczy ostatecznych autora odzwierciedla styl całego podręcznika, który został napisany w duchu powszechnie w tamtym czasie panującej neoscholastyki ${ }^{23}$. Kształt neoscholastycznej eschatologii zwięźle prezentuje Giovanni Ancona:

Eschatologia, która powstaje od połowy XIX w., epoki, w której widać narzucanie się neoscholastyki, jest zredukowana do kilku kwestii, które dotyczą prawie wyłącznie przeznaczenia eschatologicznego poszczególnej jednostki. Typowe opracowania tego okresu ujmują eschatologię w terminach „rzeczy ostatecznych"; zatem przeważa w nich reistyczna koncepcja rzeczywistości ostatecznych, aż po opracowanie niejako „topografii” zaświatów. Przesadza się więc w opisach miejsc eschatologicznych. W konsekwencji poszczególne kwestie, które są podejmowane, otrzymują formę rozważań odizolowanych i zamkniętych w samych sobie. Fragmentaryczność wydaje się stałym elementem refleksji eschatologicznej, podtrzymywanym przez siłę spekulacji o profilu scholastycznym. W tym sensie jest naturalnym, że propozycja tematów eschatologicznych nie cieszy się zbytnim zainteresowaniem, za wyjątkiem zainteresowania typu etycznego, które podkreśla związek między przeznaczeniem eschatologicznym i odpłatąa ${ }^{24}$.

Powyższa opinia dobrze opisuje także specyfikę traktatu eschatologicznego Berthiera. Potwierdza to już wspominany tytuł: O Bogu odpłacajacym, który jest jednym z powszechnie przyjętych sposobów tytułowania traktatów eschatologicznych w neoscholastycznej manualistyce ${ }^{25}$. Poza tym wystarczy pobieżny rzut oka na spis treści, żeby zobaczyć neotomistyczny charakter ujęcia rzeczy ostatecznych przez Berthiera.

22 Di Dio Rimuneratore, zob. J. Berthier, Sommario, s. 442-465.

23 Na temat neoscholastyki zob. np.: Neo-scolastica, w: G. O'Collins, E.G. Farrugia, Dizionario Sintetico di Teologia, Città del Vaticano 1995, s. 241; A. Napiórkowski, Teologie XX i XXI wieku, Kraków 2016, s. 21-34.

24 G. Ancona, Escatologia cristiana, Brescia 2003, s. 218 (Nuovo Corso di Teologia Sistematica, 13); por. R.E. Rogowski, Tendencje wspótczesnej eschatologii, „Ateneum Kapłańskie” 98 (1982) z. 1 (438), s. 17-18.

25 Zob. A. Nitrola, Trattato, s. 32-33. 21. 
Rozdział drugi, traktujący o czyśćcu, piekle i niebie został bowiem zatytułowany: O schronieniach stanu duszy po śmierci ${ }^{26}$. Także tłumaczenie eschatologicznych kwestii szczegółowych w Kompendium jest nieaktualne i z punktu widzenia współczesnej eschatologii błędem byłoby budowanie praktyki duszpasterskiej na tak przedstawionej teorii. Wystarczy podać jeden przykład: Berthier, mówiąc o losie człowieka po śmierci, stale używa kategorii „miejsca”, a czasem podaje nawet dokładniejsze informacje na temat „geografii” pośmiertnej egzystencji. O piekle pisze:

Piekło jest miejscem, gdzie są zamknięci potępieni, zaraz po sądzie szczegółowym, aby cierpieć kary wieczne. Nie wiadomo w sposób pewny, gdzie jest piekło, ale zwykle uczy się, że pod ziemią ${ }^{27}$.

Zajmuje się także miejscem, w którym dokona się Sąd Ostateczny: „Powszechnie naucza się że sąd będzie miał miejsce w Dolinie Jozafata, blisko Góry Oliwnej" 28 .

Jednak dla obecnej refleksji najważniejsze jest to, że eschatologia Berthiera jest częścią podręcznika, który według założenia autora miał spełniać funkcję bardzo praktyczną: zapewniać utrwalenie i ewentualne uzupełnienie wiedzy teologicznej duszpasterzy. Wiedza ta, także w przypadku nauki o rzeczach ostatecznych, miała stanowić impuls do działania duszpasterskiego i jego treść. Dowodem tego jest inny tekst Berthiera, stanowiący konkretny przykład zastosowania teorii w praktyce.

\section{Méthode pour assister les mourants}

Méthode pour assister les mourants z imprimatur wikariusza generalnego diecezji Grenoble z dnia 24 listopada 1897 roku została wydana w 1898 roku w drukarni Szkoły Apostolskiej w Grave (Holandia) ${ }^{29}$. Jest to niewielka broszurka, którą Berthier kolportował jako tekst samodzielny lub jako załącznik do swoich książek. Podobnie jak inne teksty jego autorstwa

${ }^{26}$ Dei ricettacoli e dello stato delle anime dopo la morte, zob. J. Berthier, Sommario, s. 445-461.

27 J. Berthier, Sommario, nr 1743, s. 451.

28 J. Berthier, Sommario, nr 1812, s. 464.

29 Zob. W. Biedrzycki, Przy łożu, s. 260. 
doczekała się licznych wydań, a także tłumaczenia na język polski pt. Metoda asystowania umierającym ${ }^{30}$, które będzie stanowiło punkt odniesienia w niniejszym artykule. Na podstawie zachowanych egzemplarzy można wnioskować, iż tekst istniał przynajmniej w dwóch wersjach. Krótszej, zawierającej samą Méthode ${ }^{31}$ oraz dłuższej, w której Berthier zamieścił dodatkowo zestaw modlitw do odmawiania przy umierających ${ }^{32}$. Polskie tłumaczenie jest tłumaczeniem dłuższej wersji Méthode ${ }^{33}$.

Okoliczności i cel powstania tekstu oddają dobrze charakter aktywności pisarskiej Berthiera. Jej autor był gorliwym duszpasterzem i rekolekcjonistą, którego lata życia przypadły na okres wielkiej laicyzacji Francji. Jej obywatele należący do niższych warstw społecznych byli w dużej mierze analfabetami, a przez to ignorantami w sprawach wiary i Kościoła ${ }^{34}$. Berthier przejęty ich losem całą swoją aktywność literacką poświęcił popularyzacji prawd wiary i moralności chrześcijańskiej - „nie uprawiał teologii «do szuflady»"35. Wszystkie jego dzieła miały ostatecznie charakter duszpasterski, użytkowy - były „ewangelizacją w pigułce”36. Ich język miał być jasny, konkretny, przystępny i zrozumiałe dla wszystkich. Wskazuje się na przykład, że Berthier zamieniał trudne określenia właściwe dla języka teologicznego na opisowe tłumaczenia zrozumiałe dla ludzi niewykształconych ${ }^{37}$.

Nie inaczej rzecz przedstawia się z Metoda asystowania umierajacym. Jest ona owocem konkretnego doświadczenia duszpasterskiego jej autora i „nie narodziła się przy biurku”38.

30 J. Berthier, Metoda asystowania umierajacym, tłum. W. Biedrzycki, Górka Klasztorna 2015 (Berthierana, 5).

31 J. Berthier, Méthode pour assister les mourants, La Salette 1898.

32 J. Berthier, Méthode pour assister les mourants, Abbaye St Antoine (Isère), br.

33 Niestety nie podano dokładniejszych informacji, które z wydań oryginalnych stało się podstawą tłumaczenia polskiego.

34 Na temat kontekstu historyczno-teologicznego pisarstwa Berthiera zob. W. Biedrzycki, Przy łożu, s. 260-262. 264-267; A.J. Sobczyk, P.J. Krupa, W kręgu duchowości świętorodzinnej, Pelplin 2007, s. 53-66; A. Bajorski, „Metoda”, s. 99-101.

35 W. Biedrzycki, Przy łożu, s. 266.

36 M. Machinek, Towarzyszyć, s. 81.

$37 \mathrm{~Np}$. fr. omniscient (wszechwiedzący) na: „Il est donc la science qui sait tout” (On jest więc wiedzą, która wie wszystko), zob. W. Biedrzycki, Przy łożu, s. 266.

38 M. Machinek, Towarzyszyć, s. 81. 
Rady i zalecenia Ojca Założyciela brzmią niemal jak rozkazy generała na linii frontu, który nie ma czasu na zbędne uzasadnienia i wprowadzenia, gdyż ważą się losy jego żołnierza ${ }^{39}$.

Już w Przedmowie kilkunastostronicowego dziełka autor jasno określa jego cel i adresatów, do których ma trafić:

W nieszczęśliwych czasach, w jakich żyjemy, łatwa metoda przygotowania umierających do stanięcia przed Bogiem wydaje się nam bardziej konieczna niż kiedykolwiek indziej. Publikujemy ją zatem: i błagamy naszych czcigodnych współbraci, którzy opiekują się duszami i wszystkie osoby pobożne, którym leży na sercu zbawienie ich braci, by ją rozpowszechniali w rodzinach. [...] Byłoby pożądanym, by przynajmniej w każdej chacie naszych wiosek, na każdej ulicy naszych miast były jakieś osoby ożywione duchem Bożym, które odszukiwałyby chorych i im towarzyszyły jak wskazujemy! Oby pobudzała ich gorliwość kapłanów! ${ }^{40}$

Duszpasterski charakter widoczny jest także w strukturze tekstu, który następuje po przytoczonej Przedmowie i poprzedzającej ją Radzie o następującej treści: „Ta metoda może służyć również bardzo owocnie do przygotowania małych dzieci i nieobeznanych do sakramentu pokuty" ${ }^{41}$.

W tekście Metody przeplatają się: teoria (katechizmowy wykład prawd wiary) i praktyka (modlitwy oraz pouczenia dotyczące zachowania się osób towarzyszących umierającym).

Korpus rozpoczyna część zatytułowana tak samo jak broszura, a mianowicie: Metoda asystowania umierajacym ${ }^{42}$. Autor wykłada w niej w prosty sposób teorię, czyli naukę o śmierci, prawdach koniecznych do zbawienia (dotyczących Boga, duszy, rzeczy ostatecznych, Kościoła), przypominając racjonalność tych prawd. Następnie Berthier przechodzi do podania treści trzech aktów, jakie wszyscy, a szczególnie umierający, powinni wzbudzać, aby przy ich pomocy, jak po „szczeblach”, wznosić się do Boga. Chodzi o akty: wiary, nadziei, miłości i żalu ${ }^{43}$. W związku z nimi podaje naukę o żalu doskonałym zmazującym wszystkie grzechy w razie

\footnotetext{
39 M. Machinek, Towarzyszyć, s. 80.

40 J. Berthier, Metoda, s. 11-12.

41 J. Berthier, Metoda, s. 9.

42 J. Berthier, Metoda, s. 13-15.

43 Zob. J. Berthier, Metoda, s. 15-17.
} 
niemożności przystąpienia do sakramentów i o znaczeniu sakramentu spowiedzi. Jednocześnie podaje kilka rad praktycznych, tłumacząc, jakie osoby mogą, a jakie nie powinny znajdować się przy umierającym ${ }^{44}$. Tę część kończy wyznanie autora, które przypomina dobra płynące ze stosowania proponowanej przez niego metody:

Szczęśliwi ci, którzy oddadzą się temu dziełu, najbardziej potrzebnemu ze wszystkich, towarzyszenia w ten sposób umierającym. Otworzą oni niebo dla mnóstwa dusz i przygotują sobie samym łaskę dobrej śmierci ${ }^{45}$.

Kolejna część broszury nosi tytuł: Polecenie duszy ${ }^{46}$. Po kilku uwagach praktycznych dotyczących zachowania się osób towarzyszących osobie w agonii (wezwanie do modlitwy, podania krucyfiksu i zapalenie świecy) podane zostaje 8 modlitw, wśród których znajdują się: Litania do Wszytkach Świętych, modlitwy do Miłosiernego Boga i świętych, do Chrystusa, do Maryi i do św. Józefa. Po nich, pod wspólnym tytułem Modlitwy pobożne $e^{47}$ autor umieszcza 4 modlitwy, z których dwie mają być odmówione w konkretnym momencie: jedna „przy ostatnim tchnieniu”, czyli w chwili konania, kiedy to „umierający powinien zrobić wysiłek wypowiedzenia ustami lub przynajmniej w sercu święte imię Jezus, Jezus, Jezus"48. Druga natomiast natychmiast po śmierci ${ }^{49}$.

Metoda asystowania umierających kończy się nienoszącym odrębnego tytułu zbiorem krótkich wskazówek praktycznych, jak należy zachować się po śmierci osoby, której się towarzyszyło. Mowa jest więc m.in. o: biciu w dzwony, ubraniu zwłok, zamknięciu oczu, włożeniu w ręce krucyfiksu i skrzyżowaniu palców, nieustannej modlitwie - szczególnie o uczestniczeniu w pogrzebie i zamawiania Mszy św.: w dniu siódmym i trzydziestym po śmierci, ale także w jej rocznicę oraz Mszy św. gregoriańskich ${ }^{50}$.

${ }^{44}$ Zob. J. Berthier, Metoda, s. 17-19.

45 Zob. J. Berthier, Metoda, s. 19.

46 Zob. J. Berthier, Metoda, s. 19-26. W tym miejscu rozpoczyna się część tekstu, która $\mathrm{w}$ oryginale francuskim jest obecna jedynie w formach dłuższych Méthode.

${ }_{47}$ Zob. J. Berthier, Metoda, s. 27-30. W polskiej publikacji broszury sekcja ta otrzymała tytuł: Modlitwy zebrane przez księdza Jana Berthiera, zob. J. Berthier, Metoda, s. 27.

48 J. Berthier, Metoda, s. 28.

49 J. Berthier, Metoda, s. 29.

50 J. Berthier, Metoda, s. 30. 
Krótka prezentacja struktury i treści tekstu Berthiera pozwala zauważyć, iż można zaliczyć go do dzieł z gatunku ars moriendi. Temat podjęty przez autora nie jest bowiem zagadnieniem nowym, lecz wpisuje się $\mathrm{w}$ wielowiekową tradycje pism mających na celu pomoc w przygotowaniu siebie i innych na tzw. dobrą śmierć, czyli prowadzącą człowieka do wiecznego zbawienia. Choć zauważa się, że nie ma bezpośrednich wiadomości na temat tego, czy Berthier znał inne dzieła z gatunku ars moriendi, jednak nie można tego wykluczyć, a nawet należałoby uznać to za bardzo prawdopodobne.

Berthier, znany przecież jako kompilator tekstów, mógł znać te przedstawienia, chociaż dzieliła go od czasów ich powstania przestrzeń kilkuset lat. Tego typu literatura była bowiem niezwykle szeroko kolportowana w Europie również w późniejszych epokach. [...] Jeżeli nawet Ojciec Założyciel nie znał tego typu literatury, to jednak mógł być pod wpływem modelu duchowości, wyrosłego z literatury ars moriendi ${ }^{51}$.

Tezę tę potwierdzają dwa fakty. Po pierwsze, tekst Berthiera wykazuje szczególne podobieństwo do dwóch dzieł: Ars moriendi Mateusza z Krakowa i De arte moriendi Jana Gersona ${ }^{52}$. Po drugie, w części Kompendium poświęconej eschatologii, Berthier odwołuje się do autorytetu Gersona, co świadczy o tym, że jego nauka nie była mu obca ${ }^{53}$.

\section{Wnioski}

Wydaje się, że wnioski z analizy dwóch tekstów Berthiera można zawrzeć w trzech następujących postulatach dotyczących eschatologii współczesnej: obecność, aktualność, spójność teorii i praktyki.

\subsection{Obecność}

Berthier nie jest nowatorski ani w swojej teologii rzeczy ostatecznych, ani w swojej praktyce towarzyszenia umierającym. W obu obszarach jedynie kontynuuje to, co w teologii i duszpasterstwie Kościoła było

51 M. Machinek, Towarzyszyć, s. 85.

52 M. Machinek, Towarzyszyć, s. 85.

53 Zob. J. Berthier, Sommario, nr 1779-1780, s. 457. 
w różny sposób obecne od ich zarania ${ }^{54}$. Ale właśnie owa obecność i kontynuacja tego, co zawsze stanowiło niezbywalny element teorii i praktyki chrześcijańskiej jest godna naśladowania. Oznacza to, że namysł nad ostatecznym losem człowieka nie może zniknąć z teologii, podobnie jak nie można porzucić troski o praktyczne formowanie ludzi do rozumienia życia, śmierci i wieczności w świetle zmartwychwstania Jezusa Chrystusa, „który przezwyciężył śmierć, a na życie i nieśmiertelność rzucił światło przez Ewangelię" (2 Tm 1, 10). Nie można więc sprawić, aby znikło chrześcijańskie przygotowanie do śmierci. O tym, że takie niebezpieczeństwo istnieje w teologii może świadczyć przywołany już tytuł kwartalnika „Communio”: Kryzys eschatologii. Natomiast obserwacje duszpasterzy, którzy w swoich parafiach widzą niewielkie zainteresowanie chrześcijańskim przygotowaniem do śmierci i rosnącą liczbę tzw. pogrzebów świeckich, są znakiem zanikania chrześcijańskiej eschatologii praktycznej55. Zatem myślenie o rzeczach ostatecznych człowieka musi wciąż na nowo stawać się obecne zarówno w teologii (teorii), jak i w duszpasterskiej posłudze (praktyce) Kościoła.

Jako interesujące przykłady realizacji omawianego postulatu można wskazać publikacje Jacka Salija OP ${ }^{56}$ i Gerharda Lohfinka ${ }^{57}$. Obaj teologowie starają się, każdy we właściwy sobie sposób, współczesnym językiem mówić o zagadnieniach eschatologicznych, łącząc: współczesne pytania, teologiczny namysł nad życiem i wiecznością, propozycje konkretnego działania.

\subsection{Aktualność}

Teoria i praktyka eschatologiczna Berthiera noszą znamię czasów, w których żył. Eschatologia neoscholastycznych podręczników i krótka instrukcja towarzyszenia umierającym wpisują się w realia drugiej

54 Na temat historii eschatologii zob. np. G. Ancona, Escatologia, s. 139-257; o historii ars moriendi zob. np. M. Włodarski, Trzy traktaty o sztuce umierania, Kraków 2015, s. 10-37.

55 Zob.Z. Waleszczuk, O znaczeniu ,ars moriendi”, „Życie Konsekrowane” (2019) nr 6 (140), s. 23-26.

56 J. Salij, Horyzonty ostateczne, Poznań 2015.

57 G. Lohfink, Am Ende das Nichts? Über Auferstehung und Ewiges Leben, Freiburg-BaselWien 2018. 
połowy XIX-wiecznej Francji. Oznacza to, że eschatologia i duszpasterstwo eschatologiczne pierwszej połowy XXI wieku powinno także odpowiadać realiom współczesnym. Co to konkretnie znaczy? Odpowiedź na to jedno z najtrudniejszych pytań kryje się w słowach kard. Josepha Ratzingera:

Chrześcijaństwo z perspektywy swojego wnętrza jest całkiem proste, jego treściową pełnię otrzymuje z zewnętrznej różnorodności ludzkich rzeczywistości, w której objawia się za każdym razem jedno i to samo ${ }^{58}$.

„Jedno i to samo" według Ratzingera może być określone na kilka sposobów, niejako z różnych stron, nie powodując jednocześnie rozbicia czy zubożenia ,jednego i tego samego". Z perspektywy eschatologicznej można więc powiedzieć: „W chrześcijaństwie chodzi tylko o śmierć i zmartwychwstanie"59. Jeśli tak jest, to zadaniem współczesnych teologów jest poszukiwanie sposobów tłumaczenia śmierci i zmartwychwstania, czyli tego "jednego i tego samego" (teologia), a zadaniem duszpasterzy - przygotowywanie na nie człowieka żyjącego tu i teraz (praktyka) ${ }^{60}$.

Wiadomo, że od czasów neoscholastycznej teologii rzeczy ostatecznych Berthiera w eschatologii jako nauce (teorii) nastąpił rozwój, który pozwala w sposób bardziej odpowiedni rozumieć i przedstawiać misterium życia, śmierci i wieczności ${ }^{61}$. Oczywistym zatem jest, że

58 J. Ratzinger, O teologii śmierci, w: Zmartwychwstanie i życie wieczne. Studia o eschatologii i teologii nadziei, red. K. Góźdź, M. Górecka, Lublin 2014, s. 287-288 (Opera Omnia, 10).

59 J. Ratzinger, O teologii, s. 287. Inne określenia użyte przez Ratzingera to: „W chrześcijaństwie chodzi tylko o miłość, czy też: w chrześcijaństwie chodzi tylko o pokorę wiary" (J. Ratzinger, 0 teologii, s. 287). Tę samą ideę choć, innymi słowami, wyraża Ratzinger także w: J. Ratzinger, Eschatologia - śmierć i życie wieczne, w: Zmartwychwstanie i życie, s. 111.

60 Zob. J. Ratzinger, Dogma e predicazione, Brescia 20052, s. 7 (Biblioteca di teologia contemporanea, 19). Jednym z przykładów może być inicjatywa duszpasterzy Apostolstwa Dobrej Śmierci polegająca a publikowaniu Materiałów formacyjnych, a także serii filmików tłumaczących główne zagadnienia eschatologiczne zob. www.apostolstwo.pl

${ }^{61}$ Temat ten został opracowany w wielu podręcznikach oraz artykułach polskich i obcojęzycznych, np.:. R.E. Rogowski, Tendencje, s. 16-30; A. Skowronek, Eschatologiczny wymiar teologii a eschatologia, „Ateneum Kapłańskie” 98 (1982) z. 1 (438), s. 5-15; M. Bordoni, N. Ciola, Gesù nostra speranza. Saggio di escatologia in prospettiva trinitaria, Bologna 20002, s. 111-167 (Corso di teologia sistematica, 10);. A. Nitrola, Trattato, s. 28-99. 
tematy eschatologiczne nie mogą być więcej wykładane jako „rzeczy ostateczne" rozpatrywane same w sobie, lecz muszą być przedstawiane jako zdarzenia mające swe epicentrum w zdarzeniu Chrystusa i dlatego rozwijane muszą być chrystologiczne ${ }^{62}$.

Jednakże w imię tego rozwoju teorii nie można zrezygnować z chrześcijańskiej praktyki eschatologicznej, czyli z ars moriendi et vivendi. Oczywiście, nie chodzie o straszenie „reportażami z góry prefabrykowanymi”, szczegółowo opisującymi, jak będzie wyglądał świat w przyszłości, albo los człowieka po śmierci ${ }^{63}$, jednak można i należy o tej przyszłości mówić zgodnie z tym, co Kościół uznaje za swoją oficjalną doktrynę. Prawdą pozostaje, że w praktyce duszpasterskiej najłatwiej odnosić się do pytań i problemów, stawianych przez konkretne osoby, dotyczących losu ich bliskich: żywych, umierających i zmarłych. Żadna lektura traktatu eschatologicznego nie zastąpi rozmowy z osobą, która kompetentnie i z wiarą przedstawia Dobrą Nowinę o życiu wiecznym. Dlatego nie należy bać się rozmów na tematy eschatologiczne, gdyż w praktyce właśnie to budzi zainteresowanie nie tylko wierzących, ale także tych pozornie obojętnych lub deklarujących się jako ateiści. Pragnienie wiecznego życia jest bowiem wpisane w naturę człowieka, a sposób, w jaki to życie pojmuje, znacząco, choć nie zawsze w sposób uświadomiony, wypływa na jego konkretne wybory w ciągu życia, a szczególnie u jego kresu.

Wszelka teoria eschatologiczna, która usuwałaby lub chociażby niebezpiecznie by rozwadniała którykolwiek z elementów nauki Kościoła na temat odpowiedzialności człowieka po śmierci za swoje życie na ziemi, nie jest żadnym rozwojem eschatologii. Przetłumaczona bowiem na praktykę będzie powodować u ludzi dezorientację, niepewność, beznadzieję lub zuchwałość odnośnie do ich wiecznego losu, a co gorsza wystawi ich na niebezpieczeństwo utraty wiecznego szczęścia. Jako przykład takich teorii eschatologicznych można wskazać wszelkie reminiscencje odrzuconej przez Kościół apokatastazy ${ }^{64}$. Dzisiaj teoria ta w praktyce

\footnotetext{
A. Skowronek, Eschatologiczny wymiar, s. 12.

A. Skowronek, Eschatologiczny wymiar, s. 11.

$64 \mathrm{~Np}$. Enchiridion symbolorum, definitionum et declarationum de rebus fidei et morum. Edizione bilingue sulla 40a edizione, a cura di H. Denzinger, P. Hünermann, Bologna 2009, nr: 72, 76,
} 1002. 
przyjmuje postać streszczającą się w stwierdzeniu: „Wystarczy być dobrym człowiekiem, żeby pójść do nieba". W konsekwencji osoby tak myślące przestają cenić żywą więź z Chrystusem w sakramentach Kościoła, kierując się w życiu tzw. „własnym sumieniem”65.

Opracowywanie teorii i praktyki eschatologicznej „tu i teraz” oznacza także odpowiadanie na pytania ludzi nam współczesnych, nawet jeśli nie są one formułowane wprost $^{66}$. Zatem może już czas, aby przemyśleć w świetle eschatologii chrześcijańskiej propozycję „szczęścia”, jaką ofiaruje ideologia LGBT (teoria), a także zastanowić się, jak wychowywać w oparciu o ewangeliczne orędzie o zmartwychwstaniu i wieczności nowe pokolenia zagrożone tą propozycją (praktyka) ${ }^{67}$. Pośrednio skłania do tego wspominana już Rada, którą Berthier zamieścił na wstępie swojej Metody: „Ta metoda może służyć również bardzo owocnie do przygotowania małych dzieci i nieobeznanych do sakramentu pokuty"68.

\subsection{Spójność teorii i praktyki}

Dobra teoria rzeczy ostatecznych pomogła Berthierowi praktycznie towarzyszyć ludziom w ich przechodzeniu przez śmierć do życia wiecznego. Konkretnym przykładem jest szczegółowe przedstawienie w oparciu o doktrynę Soboru Trydenckiego nauki o żalu doskonałym ${ }^{69}$ z uwzględnieniem jego mocy gładzenia grzechów śmiertelnych w niebezpieczeństwie śmierci ${ }^{70}$. W Metodzie Berthier wprowadza tę naukę w praktykę, gdy poleca czynić akt żalu, tłumacząc:

Otóż jest ważnym zauważyć, miłość i doskonały żal zmazuje wszystkie grzechy, nawet przed otrzymaniem sakramentu pokuty. Jeśli przed śmiercią szczerze wyrazi

65 Por. B. Kulik, Czy wystarczy być dobrym człowiekiem, żeby dostać się do nieba? Przyczynek do eschatologii praktycznej, „Teologia Praktyczna” 20 (2019), s. 53-68, doi:10.14746/ tp.2019.20.04.

66 Por. A. Skowronek, Eschatologiczny wymiar, s. 8-13.

67 Por. J. Ratzinger, Eschatologia i utopia, s. 22-23; J. Ratzinger, Bóg, s. 400.

68 J. Berthier, Metoda, s. 9.

69 Zob. J. Berthier, Sommario, nr 1050-1057, s. 269-271.

70 Zob. J. Berthier, Sommario, nr 1053, s. 270. 
się te akty bez możliwości otrzymania sakramentów, a prawdziwie ich się pragnie, jest się jednak zbawionym, nawet jeśli aż do tego momentu było się heretykiem lub poganinem ${ }^{71}$.

Praktyka eschatologiczna musi zatem posiadać swoją konkretną treść, czyli musi opierać się na konkretnej wiedzy, dzięki której można odpowiedzieć np. na następujące pytania: Dlaczego trzeba w XXI wieku nadal mówić o śmierci, niebie, piekle, czyśćcu, sądzie ostatecznym, zmartwychwstaniu? Dlaczego walczymy o ochronę życia od poczęcia do naturalnej śmierci dla ludzi, a dla zwierząt i roślin nie? Dlaczego chrześcijańskie asystowanie umierającym jest naszym obowiązkiem? Do czego ostatecznie trzeba przygotować nie tylko chorych i umierających, ale także młodych i zdrowych? Przed czym mamy uchronić ich los po śmierci? Dlaczego postęp techniki w żaden sposób nie gwarantuje szczęścia przyszłych pokoleń? Dlaczego nie da się ludzkimi siłami zbudować raju na ziemi?

Pisarstwo Berthiera było owocem jego wytrwałego studium, osobistej pobożności, misjonarskiego zapału i duszpasterskiej praktyki. Dlatego chciał ułatwić kapłanom przyswajanie i utrwalanie wiedzy teologicznej, pisząc kompendium teologii (teoria), a jednocześnie dając im do ręki metody asystowania umierającym (praktyka). Zatem dzieła Berthiera są przykładem tego, jak osobiste życie z Chrystusem w perspektywie śmierci i wieczności (praktyka osobista) ${ }^{72}$ wpływa na opracowywanie wykładni wiary (teoria), aby ta z kolei stanowiła impuls do duszpasterskiego działania (praktyka duszpasterska). Tylko wtedy teoria i praktyka nie sprzeniewierzą się swojej naturze (por. Mt 7, 21-27; Jk 1, 22).

\footnotetext{
71 J. Berthier, Metoda, s. 17.

72 Berthier, jak wspominano wyżej, przygotowywał się do śmierci poprzez odprawienie szczególnych rekolekcji osobistych. Dbał także o to, aby kapłani często oceniali swoje życie w świetle wieczności, polecając im odprawianie osobistego przygotowania do śmierci podczas miesięcznych dni skupienia, zob. J. Berthier, Le Sacerdoce. Son Excellence, Ses Obligations, Ses Droits, Ses Privilèges, Paris 1898, s. 450-453.
} 


\section{Zakończenie}

W książce pt. Kult i naśladowanie Świętej Rodziny Berthier z naciskiem wzywał do gorliwości o zdobywanie wszystkich dusz dla nieba ${ }^{73}$. Wydaje się, że zaprezentowane w tym artykule dwa teksty założyciela Misjonarzy Świętej Rodziny potwierdzają jego słowa. Poza tym jawią się jako impuls dla dzisiejszych teologów, duszpasterzy, seminarzystów, a także katolików świeckich do podjęcia z nowym zapałem myślenia i życia zgodnie z Ewangelią o życiu wiecznym z wykorzystaniem w tym względzie bogactwa Tradycji Kościoła. Nie dziwi zatem fakt, że jeden z duchowych synów Berthiera, prof. Marian Machinek MSF, komentując Metodę, stwierdził:

Przekonanie o potrzebie pamiętania o śmierci, jak też myśl o tym, by być z ludźmi umierającymi, by towarzyszyć im w ich ostatniej drodze, by przy całej trosce o minimalizację bólu i opiekę lekarską nie zapomnieć o trosce i wieczności, są nadal aktualne. Można nawet zaryzykować stwierdzenie, że jest to myśl, która urasta do jednego z priorytetów współczesnego przepowiadania Kościoła ${ }^{74}$.

Dlatego należy na nowo docenić eschatologię, której zadaniem jest otwieranie naszych horyzontów, by lepiej dostrzegać, rozumieć i poznawać rzeczywistość ${ }^{75}$. I nie powinno się zapomnieć, że „poznanie może dokonać się [...] tylko w bezustannym wzajemnym oddziaływaniu pomiędzy praktyką a teorią"76.

\section{Bibliografia} 13).

Ancona G., Escatologia cristiana, Brescia 2003 (Nuovo Corso di Teologia Sistematica,

Barnhoorn H.J., Ks. Jan Berthier. Założyciel Misjonarzy Św. Rodziny 1840-1908, tłum. Z. Kruża, Katowice 1973.

73 Zob. J. Berthier, Kult i naśladowanie Świętej Rodziny, tłum. A. Bocian, Pelplin 2019, s. 257-261.

74 M. Machinek, Towarzyszyć, 93-94.

75 Zob. J. Ratzinger, Eschatologia i utopia, s. 22.

76 J. Ratzinger, Eschatologia i utopia, s. 22. 
Bajorski A., "Metoda asystowania umierajacym” Księdza Jana Berthier jako model metody ogłaszania Królestwa Bożego, w: „Cor unum et anima una”. Księga Jubileuszowa ku czci księdza Jana Berthier Założyciela Zgromadzenia Misjonarzy Świętej Rodziny z okazji 100-lecia jego śmierci, red. A.J. Sobczyk, Pelplin 2009, s. 95-101.

Bajorski A., Pisarstwo Księdza Jana Berthier ze szczególnym uwzględnieniem „Kult i naśladowanie Świętej Rodziny”, w: „Cor unum et anima una”. Księga Jubileuszowa ku czci księdza Jana Berthier Założyciela Zgromadzenia Misjonarzy Świętej Rodziny z okazji 100-lecia jego śmierci, red. A.J. Sobczyk, Pelplin 2009, s. 102-115.

Benedykt XVI, Ostatnie rozmowy, rozmawia P. Seewald, tłum. J. Jurczyński, Kraków 2016.

Berthier J., Abrégé de Théologie Dogmatique et Morale. Avec les Notions les plus Importantes de Droit Canon, de Liturgie, de Pastorale, de Théologie mystique et de philosophie chrétienne, Lyon-Paris $1927^{4}$.

Berthier J., Compendium Theologiae Dogmaticae et Moralis. Una cum Praecipuis Notionibus Theologiae Canonicae, Liturgicae. Pastoralis et Mysticae, ac Philosophiae Christianae, La Salette-Parisiis $1898^{4}$.

Berthier J., Kult i naśladowanie Świętej Rodziny, tłum. A. Bocian, Pelplin 2019.

Berthier J., Méthode pour assister les mourants, La Salette 1898.

Berthier J., Méthode pour assister les mourants, Abbaye St Antoine (Isère), br.

Berthier J., Metoda asystowania umierającym, tłum. W. Biedrzycki, Górka Klasztorna 2015 (Berthierana, 5).

Berthier J., Le Sacerdoce. Son Excellence, Ses Obligations, Ses Droits, Ses Privilèges, Paris 1898.

Berthier J., Sommario di Teologia Dogmatica e Morale. Colle Nozioni più Importanti di Diritto Canonico, di Liturgia, di Teologia Mistica e di Filosofia Cristiana, Torino 1933.

Biedrzycki W., Przy łożu śmierci. „Metoda towarzyszenia umierającym” ks. Jana Berthie$r a$, w: Śmierć $i$ wiara $w$ życie pośmiertne $w$ świetle nauk przyrodniczych $i$ humanistycznych, red. M. Machinek, Olsztyn 2003, s. 257-267 (Biblioteka Wydziału Teologii, 17).

Bordoni M., Ciola N., Gesù nostra speranza. Saggio di escatologia in prospettiva trinitaria, Bologna $2000^{2}$ (Corso di teologia sistematica, 10).

Bóg iświat: wiara i życie $w$ dzisiejszych czasach, z kardynałem Josephem Ratzingerem (Benedyktem XVI) rozmawia Peter Seewald, przekł. G. Sowinski, Kraków 2005.

"Cor unum et anima una”. Księga Jubileuszowa ku czci księdza Jana Berthier Założyciela Zgromadzenia Misjonarzy Świętej Rodziny z okazji 100-lecia jego śmierci, red. A.J. Sobczyk, Pelplin 2009.

Enchiridion symbolorum, definitionum et declarationum de rebus fidei et morum. Edizione bilingue sulla $40^{\mathrm{a}}$ edizione, a cura di H. Denzinger, P. Hünermann, Bologna 2009.

Färber E., Towarzyszyć umierajacym. Pastoralne wskazówki duszpasterza Jana Berthiera MS (1840-1908) oraz ich dalszy rozwój w regułach zakonnych Misjonarzy Świętej Rodziny, „Nadzieja i Życie” 2 (2017), s. 14-17; 3 (2017), s. 4-7.

Jost E., Jean Berthier (1840-1908). Missionar von La Salette und Gründer der MSF, w: ,...Zu denen in der Ferne gehen...”. Missionare von der Heiligen Familie (1895-1995), Hrsg. von F. Jürgensmeier, Mainz 1995, s. 83-110. 
Jost E., Ksiądz Jan Berthier. Założyciel Zgromadzenia Misjonarzy Świętej Rodziny. Positio, t. 1: Exposé o cnotach (Informatio), t. 2: Summarium, tłum. J. Drążkiewicz, M. Ferenc, Pelplin 2007.

Krupa P., Osoba $i$ życie ks. Jana Berthier, w: „Cor unum et anima una”. Ksiega Jubileuszowa ku czci księdza Jana Berthier Założyciela Zgromadzenia Misjonarzy Świętej Rodziny z okazji 100-lecia jego śmierci, red. A.J. Sobczyk, Pelplin 2009, s. 267-274.

Kulik B., Czy wystarczy być dobrym człowiekiem, żeby dostać się do nieba? Przyczynek do eschatologii praktycznej, ,Teologia Praktyczna” 20 (2019), s. 53-68, doi:10.14746/ tp.2019.20.04.

Lohfink G., Am Ende das Nichts? Über Auferstehung und Ewiges Leben, Freiburg-Basel-Wien 2018.

Machinek M., Towarzyszyć w ostatniej drodze. „Metoda asystowania umierającym” ks. Jana Berthier a wspótczesna troska o umierających, w: „Cor unum et anima una”. Księga Jubileuszowa ku czci księdza Jana Berthier Założyciela Zgromadzenia Misjonarzy Świętej Rodziny z okazji 100-lecia jego śmierci, red. A.J. Sobczyk, Pelplin 2009, s. 79-94.

Napiórkowski A., Teologie XX i XXI wieku, Kraków 2016.

Nitrola A., Trattato di escatologia, vol. 1: Spunti per un pensare escatologico, Cinisello Balsamo (Milano) 2001.

O'Collins G., Farrugia E.G., Dizionario Sintetico di Teologia, Città del Vaticano 1995.

Pozzo G., La manualistica, w: Storia della teologia, a cura di R. Fisichella, vol. 3: Da Vitus Pichler a Henri de Lubac, Roma-Bologna 1996, s. 309-334.

Prefazione, w: J. Berthier, Sommario di Teologia Dogmatica e Morale. Colle Nozioni più Importanti di Diritto Canonico, di Liturgia, di Teologia Mistica e di Filosofia Cristiana, Torino 1933, s. 9-10.

Rampolla M., Lettera di S. Eminenza il Card. Rampolla, w: J. Berthier, Sommario di Teologia Dogmatica e Morale. Colle Nozioni più Importanti di Diritto Canonico, di Liturgia, di Teologia Mistica e di Filosofia Cristiana, Torino 1933, s. 4.

Ratzinger J., Dogma e predicazione, Brescia $2005^{2}$ (Biblioteca di Teologia Contemporanea, 19).

Ratzinger J., Eschatologia i utopia, „Communio” 38 (2018) nr 3-4, s. 5-25.

Ratzinger J., Eschatologia - śmierć i życie wieczne, w: Zmartwychwstanie $i$ życie wieczne. Studia o eschatologii i teologii nadziei, red. K. Góźdź, M. Górecka, Lublin 2014, s. 25-257 (Opera Omnia, 10).

Ratzinger J., O teologii śmierci, w: Zmartwychwstanie i życie wieczne. Studia o eschatologii i teologii nadziei, red. K. Góźdź, M. Górecka, Lublin 2014, s. 276-288 (Opera Omnia, 10).

Rogowski R.E., Tendencje współczesnej eschatologii, „Ateneum Kapłańskie” 98 (1982) z. 1 (438), s. 16-32.

Salij J., Horyzonty ostateczne, Poznań 2015.

Skowronek A., Eschatologiczny wymiar teologii a eschatologia, „Ateneum Kapłańskie” 98 (1982) z. 1 (438), s. 5-15.

Sobczyk A.J., Ksiadz Jan Berthier jako pisarz, w: „Cor unum et anima una”. Księga Jubileuszowa ku czci księdza Jana Berthier Założyciela Zgromadzenia Misjonarzy Świętej Rodziny z okazji 100-lecia jego śmierci, red. A.J. Sobczyk, Pelplin 2009, s. 317-329. 
Sobczyk A.J., Krupa P.J., W kręgu duchowości świętorodzinnej, Pelplin 2007.

Światłość świata. Papież, Kościót i znaki czasu, Benedykt XVI w rozmowie z P. Seewaldem, przekł. P. Napiwodzki, Kraków 2011.

Waleszczuk Z., O znaczeniu „, ars moriendi”, „Życie Konsekrowane” (2019) nr 6 (140), s. 19-27.

Włodarski M., Trzy traktaty o sztuce umierania, Kraków 2015. 